\title{
Sequence Stratigraphy and Sedimentary Environment of Sarvak Formation, in the Oil Field of Kuhmond (Southwest of Iran)
}

\author{
Jafar Qomi Aveili \\ Assistant Professor, Islamic Azad University of Chalus, Chalus, Iran \\ Email:j.ghomi1388@gmail.com
}

How to cite this paper: Aveili, J.Q. (2016) Sequence Stratigraphy and Sedimentary Environment of Sarvak Formation, in the Oil Field of Kuhmond (Southwest of Iran). Open Journal of Geology, 6, 1344-1360. http://dx.doi.org/10.4236/ojg.2016.610097

Received: July 4, 2016

Accepted: October 25, 2016

Published: October 28, 2016

Copyright $\odot 2016$ by author and Scientific Research Publishing Inc. This work is licensed under the Creative Commons Attribution International License (CC BY 4.0). http://creativecommons.org/licenses/by/4.0/ (c) (i) Open Access

\begin{abstract}
Sarvak formation is one of the important hydrocarbon reservoirs in the Zagros Basin that is one of the mid-Cretaceous carbonate units in Bangestan group. This formation is located in the Kazhdomi Formation of the slope. Kuhmond oil field is in the southeast of Bushehr and in the north and northwestern of Fars province. In this study, sedimentology studies, stratigraphy and sedimentary environment in Sarvak Formation were studied. Based on studies, 18 main Microfacies were diagnosed in the region that have been deposited in four facies belts including open Sea, dam, lagoon and tidal zones. According to studies, the sedimentary environment of Sarvak formation in Kohmond field was diagnosed as a ramp carbonate platform (Figure 1).
\end{abstract}

\section{Keywords}

Sequence Stratigraphy and Sedimentary Environment, Sarvak Formation, Oil Field of Kuhmond

\section{Introduction}

Sarvak Formation is a thick carbonate stratigraphic unit that is part of Bangestan and is hidden in the Zagros region and southern margins of Neotitis. According to [1], from the Albian to Campanian, a sedimentary cycle of Kazhdumi, Sorga, Ilam, Sarvak formations can be identified that mentioned sets are called Bangestan group. Jahrom and Sarvak formations form two heavy oil reservoirs in the oilfield of Kohmond.

\section{Method}

In this thesis, at first, Sarvak formation in the oil field on the Mond oil mountain was examined in terms of stratigraphy, and then it was investigated in terms of material, 


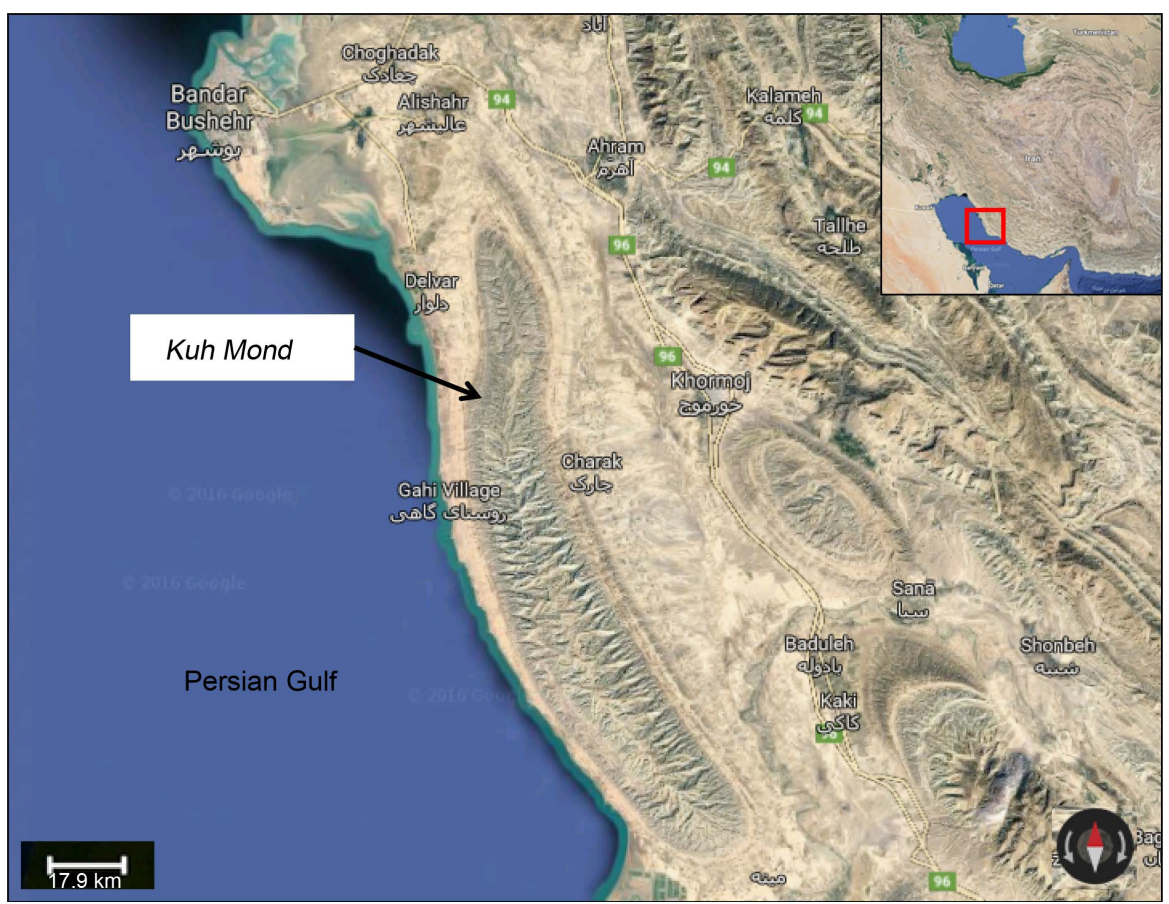

Figure 1. Kohmond on the gulf coastal side, a satellite photo in NASA world wind area.

composition, thickness and texture. Separations were carried out from the perspective of lithological rock units and at a later stage, identify and classify sedimentary facies was carried out accurately, in order to analyze facies and identify Lithology attributes, samples (thin microscopic sections) were studied and study the diagenetic processes of Laboratory study area was performed on 652 thin microscopic sections. After identifying characteristics of lithology, the suitable sedimentary environment was reconstituted [2] [3] [4] [5].

Naming carbonate facies, because of the Dunham naming importance in the oil industry, the Dunham classification method was used.

\section{Geographical Location}

Kohmond field is a heavy oil field that is the largest heavy oil fields in southwestern of Iran. This field is located in 70 kilometers southeast of Bushehr on the Persian Gulf and plain area. The Kohmond field has a length of about $90 \mathrm{~km}$ and a width of $16 \mathrm{~km}$. And it has the North West and the South East trend and it is drawn an anticline structure. The geographical coordinates of this field at the start (in the northern part of the mountain) with latitude 28,809,735 and longitude 51,138,278 and in the end, in the southern part of the mountain, with width of 28,212,609 and length of 51,396,924 ends (derived from the application NASA world wind).

\section{Drilling History}

For the first time, reserves of Kohmond were discovered in 1931 many excavations took place on it [6], so that, in the years (1931 to 1932), Monda well was excavated by rotating and impulsive drilling, intermittent, in order to evaluate Bangestan and Asmari tanks to a depth of 1169 meters (Sarvak formation) [7]. 
Monde Well 2 to 5 is excavated between 1960-1976. The drilling aim of these wells was reaching the group of "Dah Ram" and assessment of gas in these tanks, the number 6 was excavated in 1984 to evaluate the too heavy oil tanks of Jahrum, Ilam, Sarvak and Asmari and finally, well No. 7 was excavated in 1986 to evaluate and obtain more complete information from the field and access to very heavy oil of Sarvak and Jahrum formations. In 2005 to 2006, drilling well operations of well number 8 was carried out. In this field, eight wells were drilled so far that the deepest of wells is well number 5, with the action of 5055 meters [8].

Generally, in this field, the number of wells in a straight line was excavated that roughly parallel to the direction of the South East-North West along the anticline. According to the figure below, it can be explained that, most of these wells are located in the center of the anticline (Figure 2).

\section{Sarvak formation stratigraphic situation in Kohmond}

The age of the formation in the area is considered Upper Cretaceous based on studies conducted (Turonian-Cenomanian) [9] [10] [11]. The sediments of this formation are gray limestones that are pure in areas containing pyrite, oolite and sometimes lime. The middle and lower part of the formation are formed of the gray and dark brown layers of marl with inlayer cream-colored and occasionally Chile and in some areas slumberous calcareous rocks [12] [13] [14].

According to studies, Sarvak formation has two zones in the study area. These zones include Ahmadi or "shale Ahmadi" and Madood or Medved part that are known as

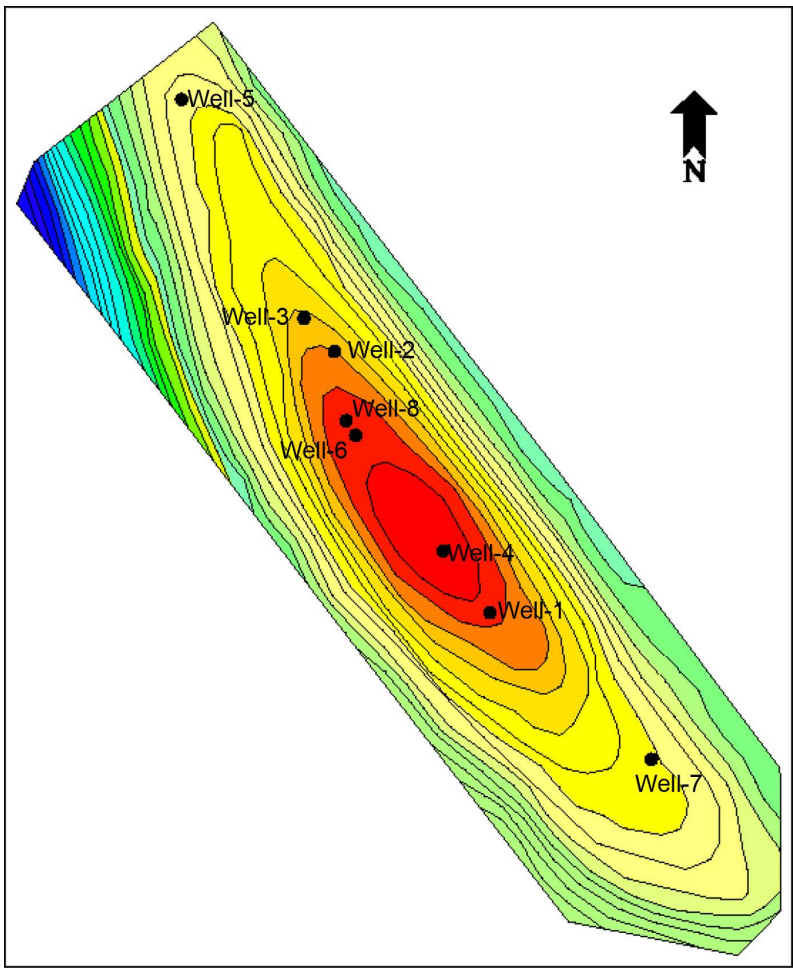

Figure 2. View of the drilled wells' location in the area of Kohmond, Sarvak Page (software petrel 2009). 
"lime Medved".

Ahmadi section: from gray to green shale with thin bedded limestone.

Medved section: from gray to green shale with thin bedded limestone. This part is more pure lime. The bottom line of this Formation with Kazhdumi formation is almost gradual and there is no unconformity.

Fossils of this formation are:

Gastropoda sp. Or biTolina concave. Trochlina spp' Shell fragm .sp

According to studies conducted in Sarvak formation in the Kohmond field, Oligostegina fossils have the most frequency among other things. The following fossils have been observed a lot in this formation.

Globigerina .sp, Echinoderm .sp. Rudist .sp-pelecypod

\section{Structural Geology of the Zone}

The Zagros Fold along with part of Azerbaijan that sediments happen during the Silurian to the Permian, probably formed part of the platform in the Iran Paleozoic. Eftekhar Nejad, 1980, it looks like the Zagros was the vibrant and marginal part of Arabic page and during the late phase of sedimentation in this area, the steeped land in effect, of gradual change along the compression forces, axis of folds is oriented to the South West. In connection with the study area, as shown in the next Figure 3, the right-turn movement of fault that is known as the Qatar-Kazeroon fault, has created changes in the northern part of the stalactites Kohmond (nose), so that it has twisted the nose of the Koohmond anticline to the [15] [16]. It has increased significantly and oriented the fractures in the studied buildings.

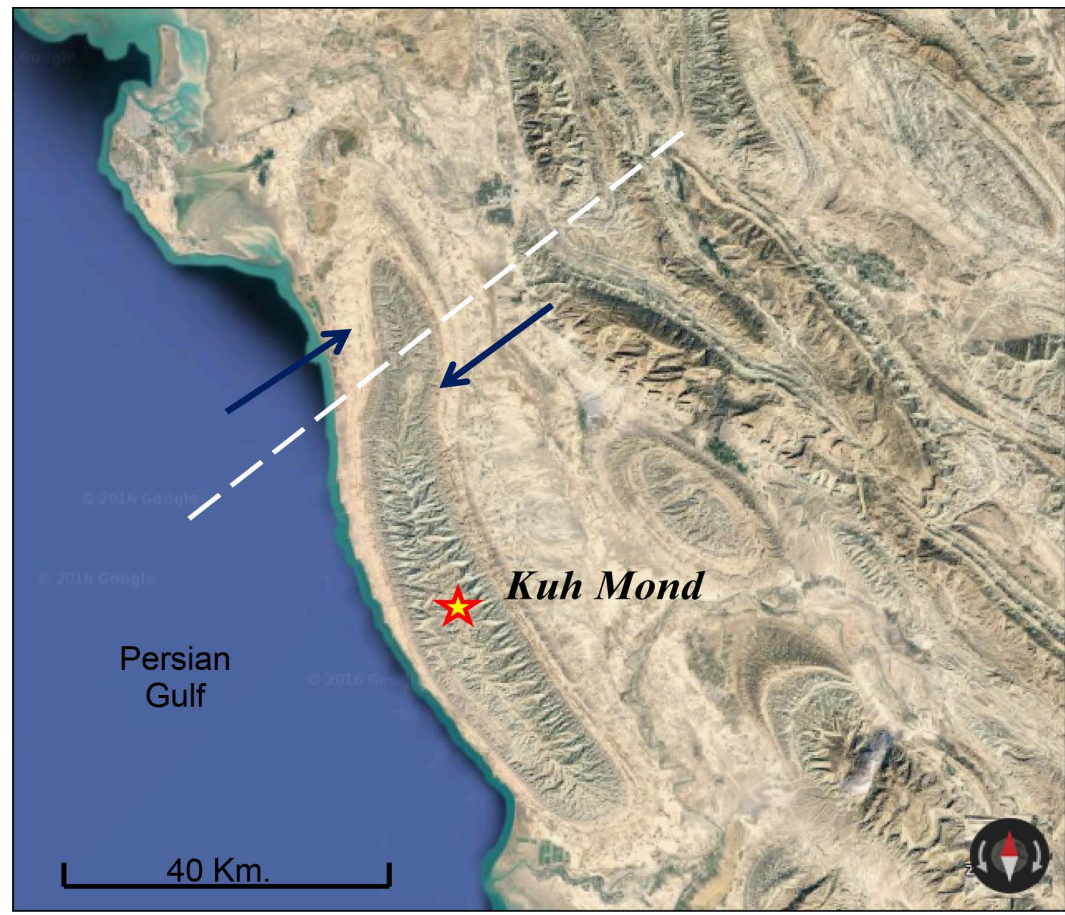

Figure 3. The impact of Kazeroon-Qatar right-turn fault in Koohmond anticline of vector Red is the color of northerly direction indicator (Google earth). 
Kohmond is a symmetrical anticline with $16 \mathrm{~km}$ wide and $90 \mathrm{~km}$ long on the coast of the Persian Gulf and South East of Bushehr. Its vertical dependency on Ilam formation is about 6300 meters and on Jahrom formation is 3500 meters. Aghajari, Bakhtiari, Mishan, Gachsaran formations formed the protrusions on the field. Mishan and Aghajari and Bakhtiari formations, respectively, are placed to the edge of the field and Gachsaran formation were scattered in the middle hump [17] (Figure 3).

A southwestern ridge of anticline Kohmond in southern Bushehr-Delaware Birikan, the photo represents the erosion in Aghajari formation located in the southwestern ridge of anticline. Also an angluar discontinuity between Aghajari and Bakhtiari formations represent an orogenic phase in the region. Look is toward the East. Adapted from [18] [19] [20].

On the surface, anticline axis has been moved by numerous faults near and in the middle of the plunge.

Results of sections that have been ticked in this area indicate that, Kohmond is a very simple anticline and its edges are extended with relatively gentle slope and perfectly symmetrical. The average slope of this anticline, on its southern slope is $15^{\circ}$ and on the northern slopes is 17 degrees. In general, the kind of fold in this field is consistent with the overall trend of folding in southern Iran. Even we can say that the movements of Hormuz Salt have been effective in its formation [21].

\section{Sequence Stratigraphy}

A depositional facies has characteristics of clear lithology and paleontology and because of it; it is separated from other facies. Differences in environmental factors are the main reason of the difference in Microfacies that in more details, it includes the effectiveness of existing activity, energy of water, oxygen, water depth, light intensity, salinity, arrival rate, clastic material and the type of stone [22] [23]. In addition to the above, the two factors of field building and climate are important factors affecting the facies and sequence sedimentary changes [24] [25]. In the study of 652 thin microscopic sections of wells (2) and (4) in oil fields Kohmond and characterization of paleontology and tissue samples, including the fossil content, type of grain, context, 18 facies and a number of subfacies were identified for Sarvak formation. These facies have been deposited in four Groups of A (open marine), B (Barrier), C (Lagoon) and D (Tidal flat).

\section{Commentaries of Sarvak formation facies in Kohmond oilfield}

Following an examination of thin microscopic sections available, the numbers of 18 facies have been identified in Sarvak formation that from the deep marine is described to the coastal area. In this division, [26] [27] [28] have been used that are frequently used to identify a variety of standard microfacies and analysis of sedimentary environments.

\section{Facies Group A: open marine facies}

The results of laboratory studies suggest that the facies of Group A have been deposited in different areas of open marine, so that its facies are placed from deep to shallow of the environment. One significant reason for it, are as follows:

1) The lack of cement in the facies Group A with Katsuni tissue suggests that this fa- 
cies are in environments with medium to low energy.

2) In $A 1$ facies, because the ingredients are fine, there are less allochems, and there are pelagic foraminifera, it seems that these sediments were deposited in more depth.

3) The frequency of skeletal fragments, such as pelagic foraminifera, such as Globigerina Oligostegina, the echinoderms species, delicate ostracods and other small species, shows that the facies related to open marine are formed [29].

4) The existence of pelagic and benthic foraminifera and fractures in components of facies, indicate that this facies are related to turbidity environment [30], which respectively the faces of the depth increases.

In studies, the most frequently of Microfacies relates to the group of marine facies. The highest number of sub-facies is seen in this group of facies that can be concluded that, Sarvak formation is deposited in a deep environment. The results of the petrographic [31] showed that most of Sarvak formation is deposited in cutting of Monde wells 8 in a deep environment that shows this is true, then we explain in the following:

\section{Microfacies A1-1 (Fossiliferous lime mudstone)}

This microfacieses, due to the presence in the depths of the sea, contain a small amount of allochems seeds, in fact, this Microfacies is the facies of open marine environment. In the studied sections of this Microfacies, a few and scattered Oligostegina Globigerina seeds and Echinoderm are seen, so that the sum of these seeds covers less than 10 percent of all schools covers, there are parts quartz, in this facies, probably by interfering deposits during the section. Quartz pieces in this facies were probably due to sediment interference during excavating operation. Diagenetic phenomena seen in this facies is dolomitization of dark joints, filled with combinations of iron oxide, pyritization, and is stylolite. In studies, the following subfacies are also seen in this area include:

1) Dolomitized fossiliferous lime mudstone

2) Pyritized fossiliferous lime mudstone

3) Sandy fossiliferous lime mudstone

\section{Microfacies A2-1 (Oligostegina Bioclast Wackstone)}

This Microfacies is an indication of the open marine sediments, and because of allochems, with high percentage, most likely, it was related to an average depth of the open marine. It contains about 10 - 40 percent Oligostegina and 10 - 20 percent other fossils, which are often pelagic foraminifera.

Most of the levels seen in Sarvak Kohmond are related to the facies and sub-facies mentioned in this group, which is a sign of the formation in the deep sea. The diagenetic processes seen in the faces, the clay and dark veins, with combinations of iron oxide, recrystallized, calcite, silification, hematite, pyrite and dolomite can be named. During laboratory studies on thin sections of 11 subfacies in this Microfacies, include:

1) Echinoderm oligostegina Bioclast wackestone

2) Castropod oligostegina Bioclast wackestone

3) Peloid oligostegina Bioclast wackestone

4) Hematitic oligostegina Bioclast wackestone

5) Hematitic pelagic Foram oligostegina Bioclast wackestone 
6) Pyritized oligostegina Bioclast wackestone

7) Dolomitized pyritization oligostegina Bioclast wackestone

8) Dolomitized oligostegina Bioclast wackestone

9) Dolomitized Globigerina oligostegina Bioclast wackestone

10) Silty oligostegina Bioclast wackestone

11) Ostraced oligostegina Bioclast wackestone

12) Pelecyped oligostegina Bioclast wackestone

13) Gastropod oligostegina Bioclast wackestone

\section{Microfacies A2-2 (Echinoderm Bioclast Wackestone)}

This microfacieses is seen more in-depth intermediate of the open sea, despite abundant Echinoderm, it relates to the open sea facies. It contains less than 40 percent Echinoderm, and other fossil fragments, which these fragments constitute between 10 20 per cent of sections. This microfacieses has subfacies, which include the following.

1) Oligostegina Echinoderm Bioclast Wackestone

2) Orbitolina Echinoderm Bioclast Wackestone

\section{Microfacies A2-3 (Globigerina Bioclast Wackestone)}

This facies can be seen in the middle depths of the open sea and includes pelagic components: It contains about 10 - 40 per cent Globigerina, 10 per cent fossil fragments, and other pelagic and benthic foraminifera. This allochems were floating in the context of microcrystalline and less in Micro Spar. Diagenetic processes, in this facies, can be referred to dolomitization, pyrite and micritization. Much number of sub-facies has been diagnosed in the sections of the study that include the following:

1) Pyritized Silty Globigerina Bioclast Wackestone

2) Oligostegina Globigerina Bioclast Wackestone

3) Orbitolina Globigerina

In the image, we can see referenced facies images. By viewing these images, we can see that, the formation environment of these facies was in deep to shallow opening marine (Figure 4).

\section{Microfacies A2-4 (Pelagic Foraminiferal Bioclast Wackestone)}

This facies contains some fossils and about 30 percent pelagic foraminifera, which are floating in the context of microcrystalline with the parts of Microspars. The formation environment of this Microfacies is the middle depths of the open sea.

\section{Microfacies A3-1 (Oligostegina Bioclast Packestone)}

This facies can be seen in the shallow open sea. In the observed sections, it contains about 60 - 80 percent Oligostegina fossil and about 10 percent other fossils often contain fossils of pelagic such as Headbergela, Globigerin. These allochems were seen in microcrystalline and Microspar background.

\section{Microfacies A3-2 (Echinoderm Bioclast Packestone)}

This facies are more related to the shallow open sea and contains more than $60 \%$ of the Echinoderm, other fossils of open sea environment and less amount of allochems were related to other environments (Figure 4). In this facies, among diagenetic processes, dolomitization can be referred. In studies, some subfacies are identified that include: 

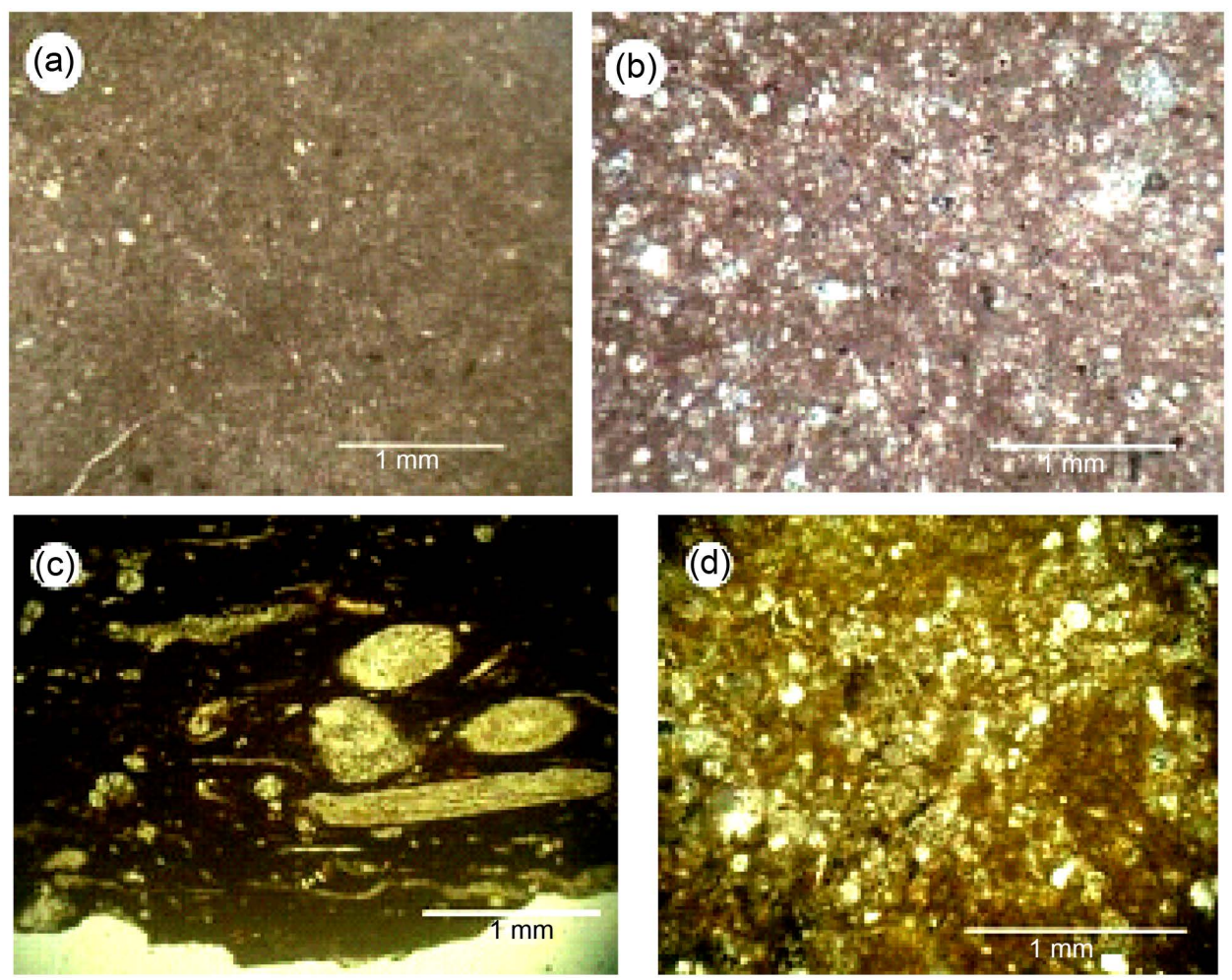

Figure 4. View of facies in open sea environment. (a) Microfacies A1-1 (fossiliferous lime mudstone). Environment: open sea, high depth, section depth, 4684 foot, normal light. (b) Micro-facies A2-1 (oligosteina bioclast wackestone). Environment: open sea, normal depth, section depth, 4604 foot, plorizing light. (c) Microfacies A2-2 (echinoderm bioclast wackestone). Environment: open sea, normal depth, section depth, 4640 foot, normal light. (d) Microfacies A2-3 (globigerina bioclast wackestone). Environment: open sea, normal depth, section depth, 4500 foot, normal light.

1) Oligostegina Echinoderm Bioclast packestone

2) Gastropod Echinoderm Bioclast packestone

3) Polomitized Echinoderm Bioclast packestone

\section{Facies Group B: facies of the barrier (Barrier Facies)}

Microfacies B1-1 (Rudist coral Bandstone)

Coral fragments and Rudists include this Microfacies that are floating in the microcrystalline and Zlineh of cement. The size of these parts was up to about $1 \mathrm{~mm}$, which are located side by side and in fact, it shows a barrier environment. In the seen sections, examples of this facies have a very low frequency, which can be considered the absence of thin sections of drill core, as one of the reasons. Subfacies Peloid Bioclast Grainstone is seen in the sections of this facies that, in fact, it emphasis on the faces in the barrier (Figure 5 and Figure 6).

\section{Facies Group C: Lagoon facies}

This facies contains the Gastropor, bivalves, Brakiopo, benthic, fuzulin, Meliolida, Pelecypoda, ostracods, Beriozda, algae, and even parts of pelagic foraminifera such as Globigerina and Oligostegina, which in fact, they are dependent on the wetland environment. 

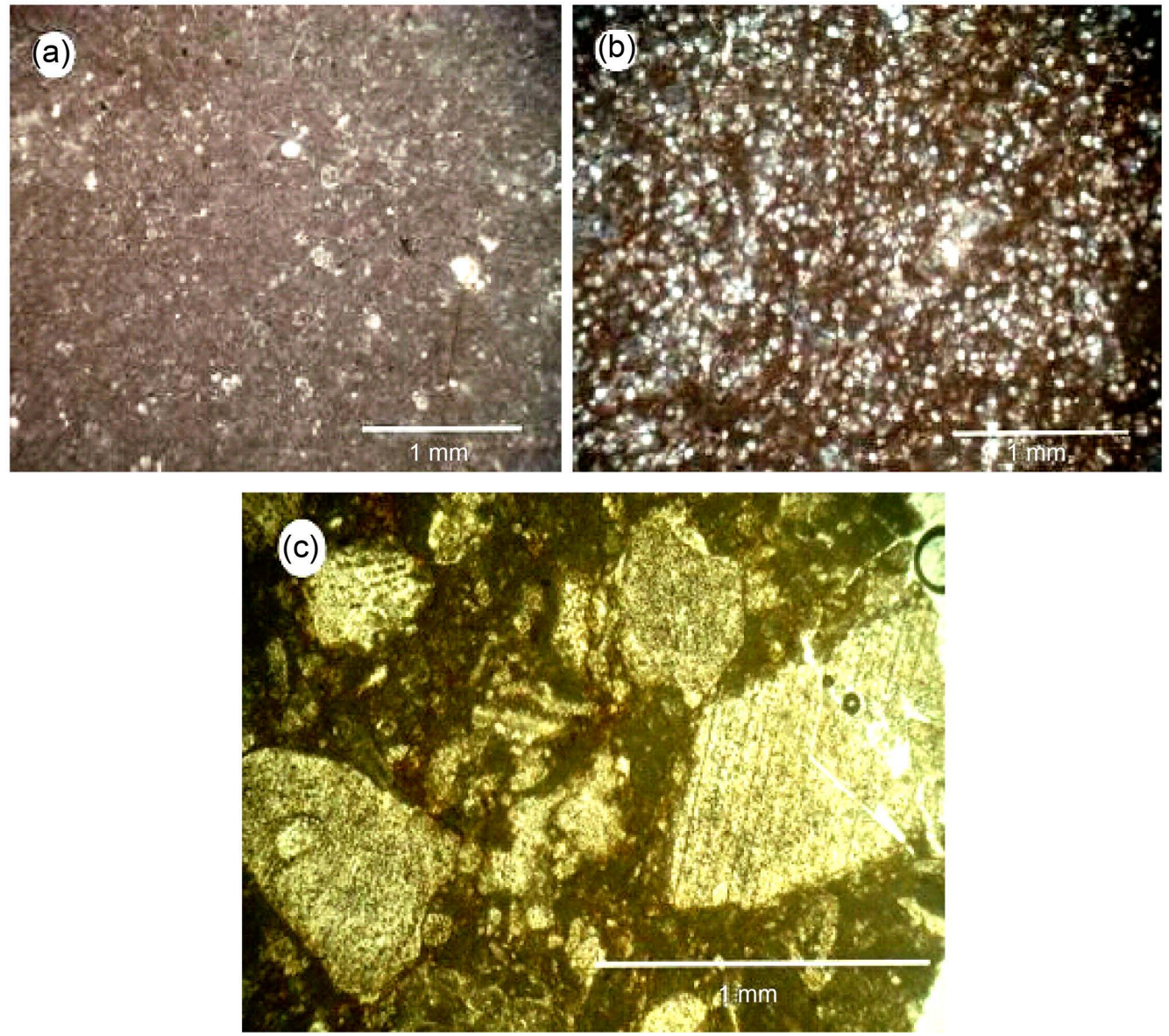

Figure 5. View of facies in open sea environment. (a) Microfacies A2-4 (pelagic foraminiferal bioclast wackestone). Environment: open sea, high depth, section depth, 4412 foot, normal light. (b) Microfacies A3-1 (oligosteina bioclast lime packeston). Environment: open sea, low depth, section depth, 4134 foot, normal light. (c) Microfacies A3-2 (echinoderm bioclast lime packeston). Environment: open sea, low depth, section depth, 4325 foot, normal light.
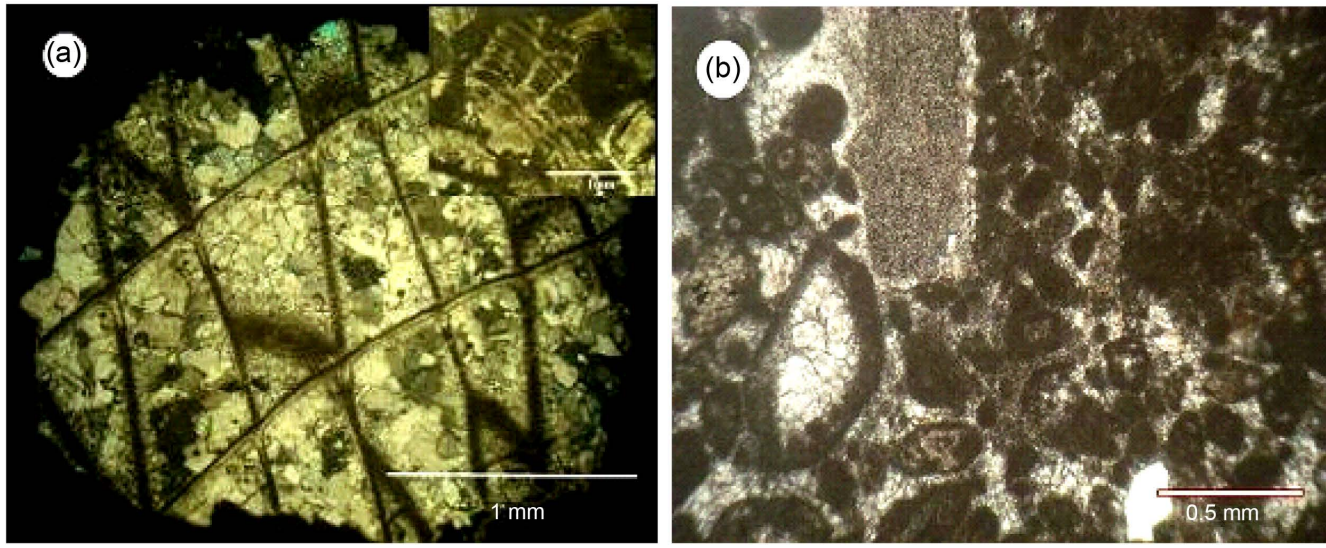

Figure 6. Facies in barrier environment. (a) Microfacies B1-1 (rudist coral bandstone) rudist section is on the right side of picture and the coral is in the center, section depth, 1010 foot, Well No4, plorizing light. (b) Subfacies (peloid bioclast grainstone) that is an emphasis on barrier environment. it should be mentioned that this subfacies are seen in some parts of sections, plorizing light. 
Given that studies in this thesis were done on the existence of stratigraphic excavation, stratigraphic is not a far-fetched conflicts.

\section{Microfacies C1-1 (Fossiliferous mudstone/shale)}

Shale or mudstone Biocalcity contains this facies. Mudston Biocalcity includes Ostracods, Brachiopods, Bivalves, and Gastropor and Benthic foraminifera. These fossils can be seen in the very low level in the section and are floating in the field of microcrystalline or in part Microspar. Joints filled with iron, dolomite and hematite are diagenetic processes in this facies. In the study of environment, subfacies are seen that includes the following components:

1) Shell fragment mudstone

2) Dolomitized fossiliferous mudstone

3) Sany Fossiliferous mudstone

4) Peloid Gastropod Bioclast Wacestone

5) Hematitic Gastropod Bioclast Wackestone

6) Pyritization Gastropod Bioclast Wackestone

\section{Microfacies C2-1 (Gastropod Bioclast Wackstone)}

This microfacieses contains 10 percent orbitolinid, Pelecypoda, Echinoderm, Oligostegina and other fossils that are mostly benthic and have Gastropod about $30-40$ percent.

In this facies, allochems are floating in the field of Microcity and are compact in some parts, and show medium deep of lagoon. Diagenetic phenomena can be referred to cementation calcite, micritization, recrystallized, micritization, succession and dolomitization.

1) Hematitic oligo gastropod bioclast vaokstone

2) Pelecypoda gastropod bioclast.

The following subfacies in studies of Microfacies have been observed that include:

1) Echinoderm Gastropod Bioclast Wackestone

2) Orbitolina Gastropod Bioclast Wackestone

3) Peloid Gastropod Bioclast Wackestone

4) Dolomitized Gastropod Bioclast Wackestone

5) Pyritization Gastropod Bioclast Wackestone

6) Hematitic Oligo Gastropod Bioclast Wackestone

7) Hematitic Gastropod Bioclast Wackestone

i) Hematitic oligo gastropod bioclast vaokstone

ii) Pelecypoda gastropod bioclast

\section{Microfacies C2-2 (Peloid Bioclast Wackestone)}

The microfacieses, due to low grain, relates to the average depth of the lagoon. Bivalves, algae, Beriozda, Gastropod, Echinoderm and brachiopods are Lagoon indicators. Allochems are surrended by Microcytic background and in some parts by Calcity cement. Veins filled with iron, stylolite, recrystallized pyrite, micritization, dolomitezation can be noted.

In studies, subfacies for Microfacies have been intended that include: 
1) Gastropod Peliod Bioclast Wackestone

2) Polomitized Peloid Bioclast Wackestone

\section{Microfacies C2-3 (Orbitolina Bioclast Wacestone)}

This microfacieses has 10 - 20 percent gastropod, MiloLida, ostracods, Pelecypoda, Echinoderm, bivalves, Peliod, and fossils, and has about 30 percent orbitolinids parts. Allochems are floating in the Microcytic background. These microfacies are related to the middle part of the lagoon. Dolomitization, cementation, micritization and hematite, recrystallization and succession are processes of diagenetic.

Below sub-faces are recognizable in following facies (Figure 7).

1) Gastropoda orbitolina Bioclast Wackestone

2) Echinoderm orbitolina Bioclast Wackestone

3) Peloida orbitolina Bioclast Wackestone

4) Miliolida orbitolina Bioclast Wackestone

5) Sandy Miliolida orbitolina Bioclast Wackestone

6) Dolomitized orbitolina Bioclast Wackestone

7) Sandy orbitolina Bioclast Wackestone

8) Sandy Hematitic orbitolina Bioclast Wackestone

\section{Microfacies C2-4 (Pelecypod Bioclast Wackestone)}

This microfacieses, in the studies contains 20 to 40 percent Pelecypod seeds and about 10 percent other fossils such as Brachiopods, bivalves, ostracods, Echinoderm,
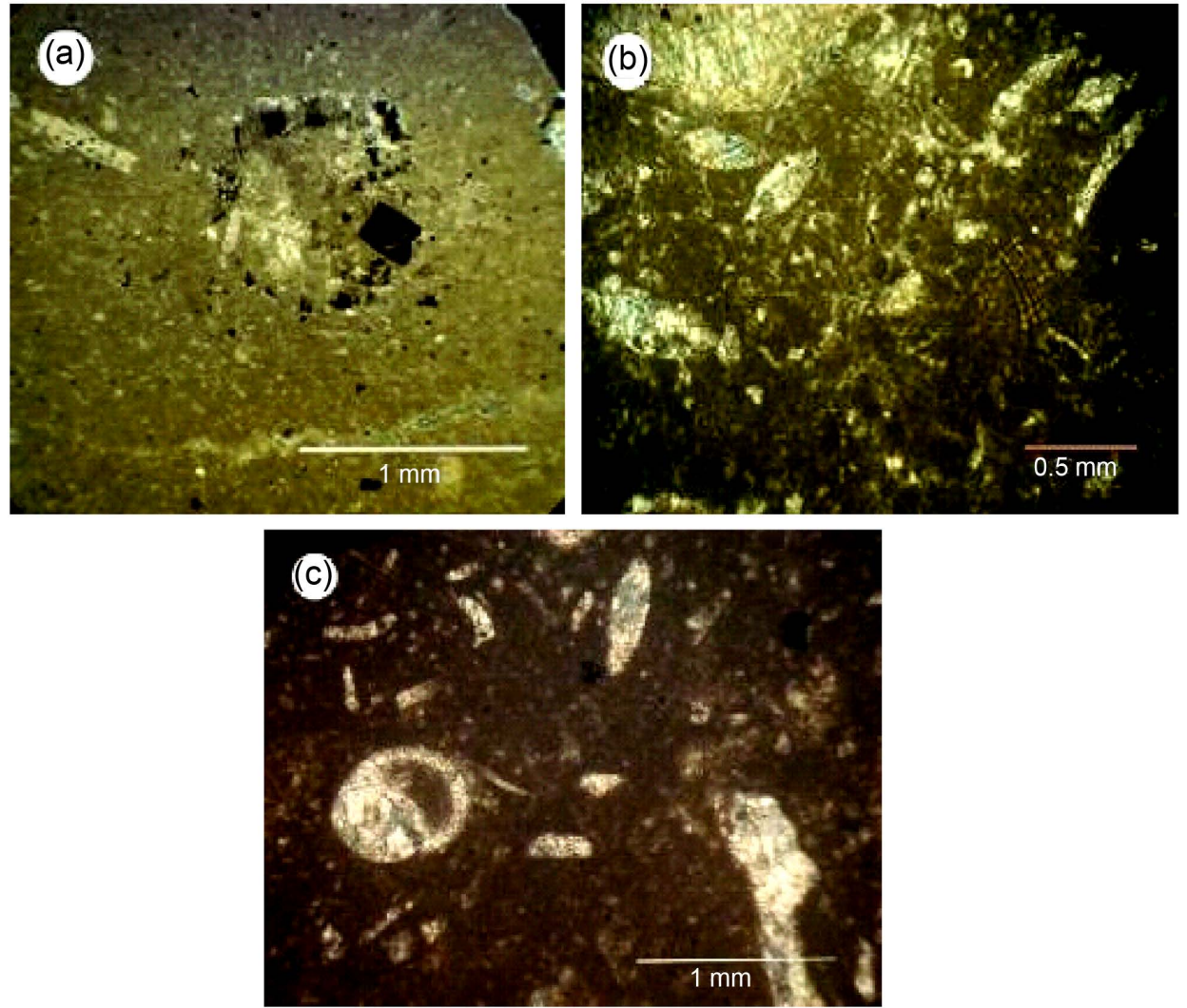

Figure 7. View of lagoon facies microfacies. 
Oligostegina, Gastropod, Globigerina and other allochems especially benthic seeds. The formation environment of this facies is in the middle deep of the lagoon. Hematite, the replacement, dolomite, calcite and cementation are diagenetic processes. The following sub-facies were identified for this facies:

1) Oligostegina Pelecypod Bioclast Wackestone

2) Globigerina Pelecypod Bioclast Wackestone

3) Hematitic Pelecypod Bioclast Wackestone

\section{Microfacies C2-5 (Benthic Foraminiferal Bioclast Wackestone)}

This microfacies contains about 30\% of Foraminiferal, Gastropod, Echinoderm, Textolaria, and ostracod, Meliolida that are floating in a field of microcrystalline and are formed from large parts of Foraminifera that are related to the benthic environment. Diagenetic processes including cementation, calcite, the dolomite and succession in the sections of facies can be observed. The followin sub-facies are seen in studies:

Sandy Benthic Foraminifer Bioclast Wackestone

\section{Microfacies C3-1 (Orhitolina Bioclast Packstone)}

This microfacies contains a large amount of bioclast that these bioclasts cointain generally orbitolinids and less Pelecypod, ostracods, Textolaria and Meliolida, Gastropod, very large Echinoderm that these are in the context of micritic matrix. This microfacieses relate to shallow Lagoon, due to large amounts of allochems, because in the shallow depth, allochems are more. In the process of diagenesis of this facies, calcite and cement replacement can be noted. The following sub-facies are seen in this Microfacies:

Echinoderm Orhitolina Bioclast Packstone

\section{Microfacies C3-2 (Pelecypod Bioclast Packstone)}

In this Microfacies, Pelecypod, pieces of Gastropod, ostracods and a small amount of Oligostegina and Globigerina are the main components of this Microfacies, which has very large Pelecypod and are in the less cement and often micritic background, which is why, the probability that this microfacies relates to the lagoon environment is very high. This facies is related to shallow lagoon. From this microfacies diagenetic process, we can refer to hematite, replacement, calcite, the dolomite and cementation. The following sub-facies are in this microfacieses:

Hematitic Pelecypod Bioclast Packstone

\section{Microfacies C3-4 (Gastropod Bioclast Packstone)}

Meliolida, Echinoderm, Textolaria, orbitolinid and the gastropod fossils include this facies, that often, are present in the microcrystalline environment and can be concluded that this Microfacies relevant to lagoon environment. Due to the abundant presence of allochems, the forming environment of this facies can be considered in shallow and high energy of the lagoon. Cementation, dolomitation, calcitation, and the density are the diagenetic processes of this microfacies.

The following two sub-facies are seen in studies that include:

1) Oribitolina Gastropod Bioclast Packstone

2) Echinoderm Gastropod Bioclast Packstone 


\section{Facies Group D: Tidal Flat Facies}

One of the features of this facies is original bird's eye that this has not been seen due to the high fragmentation in the studied levels. Dolomitic lime and dolomite are part of this facies (Figure 8 and Figure 9).

\section{Microfacies D1-1 (Dolomitized mudstone)}

In this facies, the absence of allochems to the specified amount and the presence of
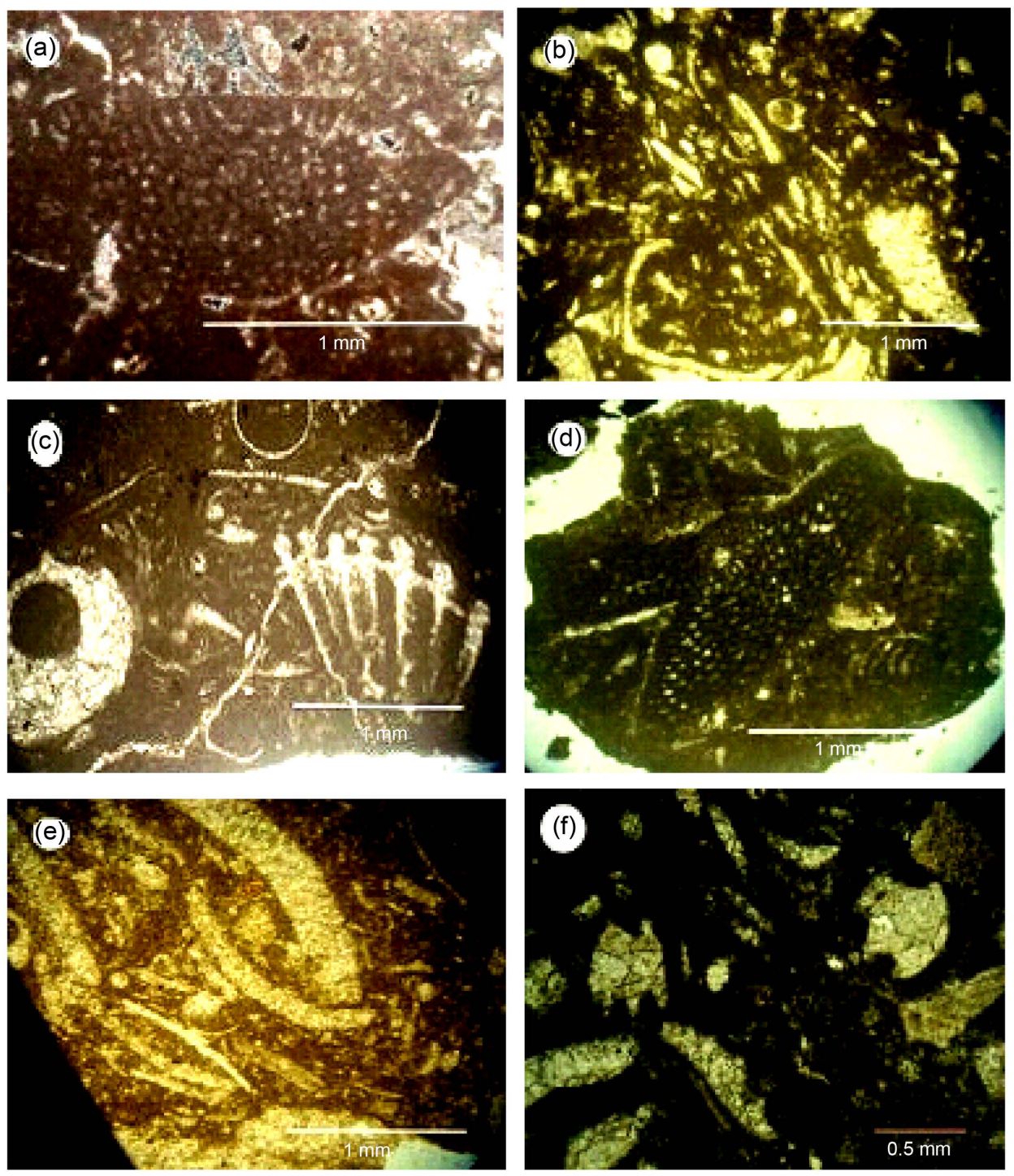

Figure 8. Display of microfacies in lagoon facies. (a) Microfacies C2-3: (orbitolina bioclast wackestone). Formation environment is normal depth of lagoon, No 2, and normal light. (b) Microfacies C2-4: (pelecypod bioclast wackestone). Formation environment is normal depth of Lagoon, No 2, and normal light. (c) Microfacies C2-5: (benthic Foraminifer bioclast wackestone). Formation environment is normal depth of Lagoon, well No 2, and normal light. (d) Microfacies C3-1: (orbitolina bioclast wackestone). Formation environment is low depth of pond, well No 2, and normal light. (e) Microfacies C3-2: (pelecypod bioclast wackestone). Formation environment is low depth of lagoon, well No 2, and normal light. (f) Microfacies C3-4: (gastropod bioclast wackestone). Formation environment is low depth of lagoon, well No 2, and normal light. 

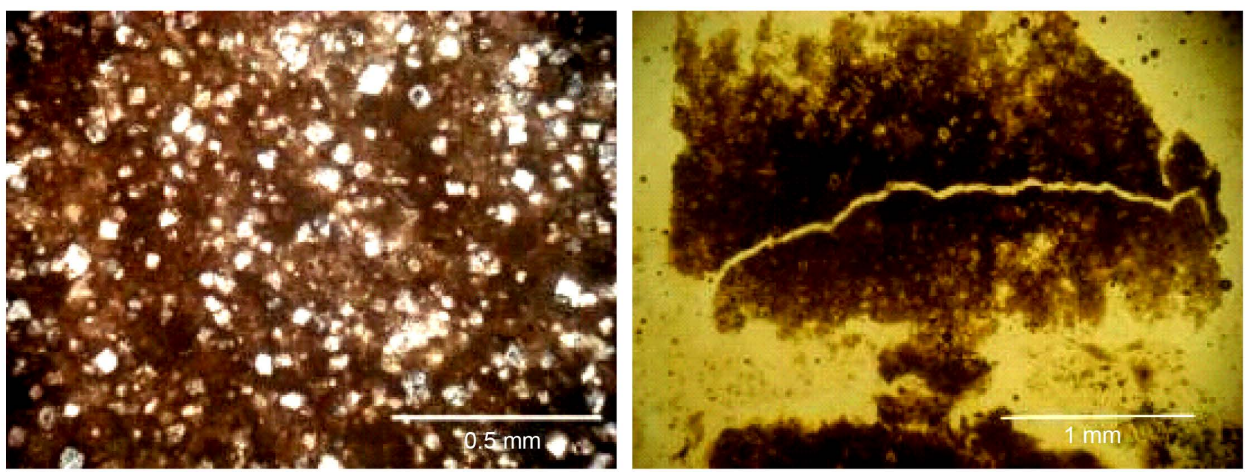

Figure 9. Display microfacies group D1 contains dolomite seeds that are obvious in the image and due to fine dolomites and lack of specified allochems, tidal environment is more likely, section depth: 4610 foot, well No 2, normal light, enlarge $\times 1$.

abundant small dolomite crystals and sub-facies of Dolomitized and Hemtitic fossilliferous mudstone, Dolomitized fossiliferous mudstone can likely be an evident of tidal flat stack.

\section{Depositional environment and depositional model}

Depositional environment includes a part of the Earth's surface that can be distincted according to their chemical, physical and biological features from the surrounding environment. This environment includes in balance corrosive environments and depositional environment. In the study of ancient depositional environments, because the sequence of sedimentary are well maintained in stratigraphic column, they can better be reviewed and reconstructed [30]. Reconstruction of ancient sedimentary environments and study the lateral and vertical relation and sedimentary facies matching together is carried out according to the Walter law [31] and their comparison with recent and ancient sedimentary environment.

Interpretation and analysis of sedimentary environments, based on sedimentary structures and microfacies analysis, and lateral and vertical facies changes, based on Wilson and Flugel [32] [33], has led to present a sedimentary model from deposits of Sarvak carbonate in Kohmond. Accordingly, based on the information and investigation, the proposed model for a possible sedimentary environment of Sarvak on the Kohmond field was diagnosed a ramp carbonate platform (Carbonat Ramp).

Alsharhan \& Nairn, 1997, knew Zagros Basin and the Persian Gulf as a vast platform environment that the North East margin of this platform has been affected as a gentle but with a stable Subsidence (Subsidence) since the Permian [34].

In general, carbonate platform can be divided into two categories:

\section{1) Carbonat ramp}

\section{2) Carbonat self}

Carbonate ramps of the beach are continuing with a very quiet and very low slope facing the sea. If this beach continuation or in another word, the bottom of the sea ends to the high depth points, it is called Homocline Ramp, but If this low slope, continues with an increase to the high depth points, it is called Distally Steepend Ramp. According to the deposition of carbonate ramp, these ramps are divided into three sections, 
which are applicable for most sequences ramp [34] [35] [36].

1) Inner Ramp: it is an area above the waves (FWWB), where, waves and flow regime are often interconnected. Tidal Flat environments, Beach and Lagoonal can be identified in the inner ramp. Minor changes in the sea level and the amount of subsidence are often affected on the inner ramp environment, where the water depth is less [36].

2) Mid Ramp

This ramp is ranging from the effects of normal waves (FWWB) and the effect of storm waves (SWB), where, the sea floor is affected by the long waves. Sedimentation in this zone is more than the other zones.

\section{3) Outer Ramp}

This ramp extends from under the effect of storm waves to the floor of the basin. In some small systems of ramps, the depth is so low that a storm layers will be created even in the outer ramp zones. In this area, changes in sea level affect the position of waves [37].

The importance of carbonate ramps is more due to the oil reservoirs that is formed because of changes in sea level and ramp-ups in various sectors.

\section{Depositional model of Sarvak Formation in Kohmond}

Reviewing the facies of Sarvak in oil field Kohmond and comparing this set, indicates that, sedimentary environments of Sarvak, in this field, was a carbonate ramp and represents deposition, in an inner ramp, middle ramp (mid ramp) and more in outer ramp (outer ramp) in the pelagic and semi-pelagic sections. Similarly, studies [38] confirm the existence of sedimentary model of the ramp (Figure 10).

\section{Conclusions}

Sarvak formation is in the region of Cretaceous carbonate unit.

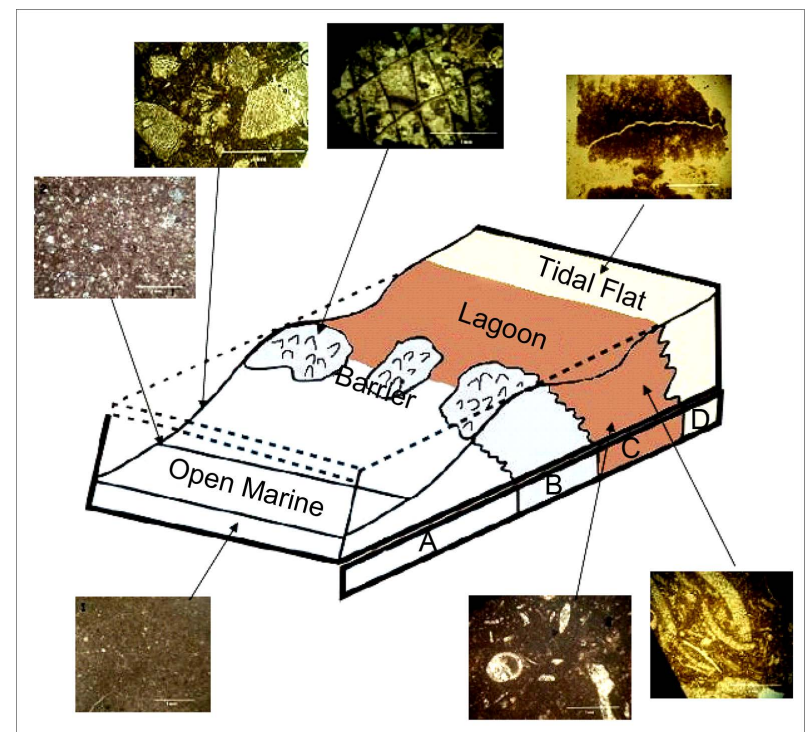

Figure 10. Display of sedimentary model of Sarvak in oil field Kohmond. 
After studying thin microscopic sections, it is determined that the area is affected by diagenetic phenomena such as dissolution, micritization, dolomitization, stylolitization, iron bearing, pyrite and cementation.

After studying thin microscopic sections available, 18 facies were identified in Sarvak. From the deep basin toward the inland marine, 4 environments of open marine, barrier, ponds or lagoons and tidal zones have been sitting.

Open marine environment with frequency of Echinoderm, Oligostegina, Globigerina, barrier with appearance of abundant Rudists, Ploid Greenstone and coral, lagoon with the frequency of Miliolids, the ploidy and Orbitolina and tidal zones with appearance of fine-grained dolomite in Madaston bed have been distinguished.

Cretaceous Sea has been an abundance of living organisms and has been associated with the sea.

\section{References}

[1] Adabi, M.H. (2004) Sediment Geochemistry. Land Arian Press, Iran, 4448 p.

[2] Eshtiklin, Y. and Sotudeh, N. (1977) Culture of Stratigraphy in Iran. GSI, Iran, 410 p.

[3] Afshar Harb, A. (2003) Petroleum Geology Books. Publications PNU, Iran.

[4] Agha Nabati, A. (2004) Iran Geology. Geological Survey of Iran.

[5] Al-Ali, M., Feiz Nia, S., Esmaeili, A. and Shahrooi, A. (2007) Review the Microfacies and Depositional Environment of Sarvak in the North West of Behbahan (Anticline Bangestan), Proceedings of the Eleventh Geological Society of Iran, Iran, January 2007, 632-635.

[6] Khosrow Tehrani, K. (2007) Microfacies. Tehran University Press, Tehran.

[7] Dashti, A.W. (1985) The Final Report of Exploration Well, No. 6 Kohmond, Volume 1, Directorate General of Geology Expansion. Geological Issues, Iran.

[8] Rahimpour Bonab, H. (2005) Carbonate Lithology, Diagenesis Relation and Porosity Evolution. Tehran University Press, Tehran, 487 p.

[9] Rahimnejad, A., Vaziri Moghadam, H., Seyrafian, A. and Amiribakhtiari, H. (2006) Biostratigraphic and Microfacies of Sarvak in Gachsaran Oil Field (Well No. 55). Journal of University of Isfahan, 23, 87-103.

[10] Rezaei, M.R. (2005) The Book of Petroleum Geology. Tehran University Press, Tehran, 472 p.

[11] Raisi, A. and Lasemi, Y. (2000) Sedimentary Environments Microfacies and Sequence of Asmari Formation (Oligo-Miocene) in South Dezful Embayment. Proceedings of the Fourth Symposium of Geological Society of Iran, Iran, January 2000, 45-53.

[12] Tabibi, M. (1985) Underground Fracture Study of Kohmond, Report No. 7. The Heavy Oil Exploration Project.

[13] Gholami, P., Adabi, M.H. and Arbab, B. (2007) Microfacies, Geochemical and Petrophysical Studies of Sarvak (Black Mountain Cross and Monde Wells). The Twenty-Sixth Meeting of Earth Sciences, Tehran, 24-32.

[14] Gholami Zadeh, P. (2008) Geochemical, Microfacies and Determine the Reservoir Properties of Sarvak in Level Surface in Black Mountain (East Borazjan) Underground Section of Kohmond, Well No. 8 (Khormoj). Geological Issues, 36.

[15] Farzadi, P. (1992) Depositional Environments and Microfacies Study of Sarvak from Bangestan Group in Open Anticline (North East of Kangan Ward). Master Thesis, University 
of Teacher Education, Iran.

[16] Folk, R.L. (2008) Petrology of Sedimentary Rocks. The Aryan Land Publication, Iran, 381 p.

[17] Ghalyayi Zadeh, M. (2008) Faces of Enhanced Recovery of Heavy Oil Reservoirs, Exploration and Production Journal. The Journal of the National Iranian Oil Company Specialized Technical, 3, 25-36.

[18] Kalantari, A. (1992) Stratigraphic and Zagros Microscopic Facies. The National Iranian Oil Company, Iran, $421 \mathrm{p}$.

[19] Lasemi, A. and Jalilian, A.H. (1997) Microfacies Study of Deposition Environment in Sarvak in Khuzestan and Lorestan. Journal of Earth Sciences, 6, 50-56.

[20] Motiei, H. (1995) Iran Petroleum Geology-Geology of the Zagros 1. Publications GSI, Iran, $1009 \mathrm{p}$.

[21] Motiei, H. (2003) Iran's Geology, Stratigraphy of Zagros. GSI Press, Iran, 536 p.

[22] Malek Zadeh, R. (1985) Estimation of Darja-Kohmond Oil in Sarvak and Jahrum Formation. Evaluation Office Cabinets.

[23] Mousavi Harami, R. (2010) Sedimentology. Astan Quds Razavi, Mashhad, 456 p.

[24] Nabavi, M. (1976) Geological History of Iran. The GSI, Iran, 109 p.

[25] Nouri, B. (2008) Geological and Petrophysical Evaluation of Sarvak in Hendijan Oil Field Located in the Persian Gulf. Master's Thesis, Azad University, North Tehran Branch.

[26] O’Brien, C.A.E. (1950) Tectonic Problems of the Oilfield Belt of South-West Iran. 18th International Geological Congress, 6, 45-58.

[27] Adams, A.E., Mackenzie, W.S. and Gulford, C. (1984) Atlas of Sedimentary Rock under the Microscope. Longman, Harlow, 104.

[28] Alavi, C. (1991) Tectono Stratigraphic Evolution of the Zagrosides of Iran. Geology, 8, 144149. http://dx.doi.org/10.1130/0091-7613(1980)8<144:TEOTZO >2.0.CO;2

[29] Alsharan, A.S. and Narin, A.E.M. (1997) Sedimentary Basins and Petroleum Geology of the Middle East. Elseveir, Amsterdam, 843.

[30] Altman, T.D., David, A., Fate, T.H., Harrison, R., Price, J.M. and Harris, M.H. (1987) Heavy Oil Reservoir Study Kuh-e-Mand Field. Iran MCA-41-T, Hoston.

[31] Burchette, T.P. and Wright, V.P. (1992) Carbonate Ramp Depositional System. Sedimentary Geology, 79, 3-57. http://dx.doi.org/10.1016/0037-0738(92)90003-A

[32] Burley, S. and Worden, R. (2003) Sandston Diagenesis: Recent and Ancient. Reprint Serint Series Volume 4 of the International Association of Sedimentologists. Black Well Publishing Ltd., Cornwall, 649.

[33] Clavier, C. and Rust, D.H. (1976) MID Plot: A New Lithology Technique. Log Analyst, 17, 16.

[34] Saxton, J. (2006) OPEC and the High Price of Oil: A Join Economical Commitical Study, USA.

[35] Schlumberger Middle East SA (1981) Well Evaluation Conference. United Arab Emirates Qatar, $120 \mathrm{p}$.

[36] Schlumberger (2002) Schlumberger Log Interpretation: Principles/Applications. Houston, $250 \mathrm{p}$.

[37] Schlumberger (2005) Petrel Introduction Course, Petrel 2008. 555 p.

[38] Stocklin, J. (1972) Iran Central, septentrional et oriental, Lexiqu Stratigraphique International, 111, Fascicule 9b, Iran. Centre National de La Recherche Scientifique, Paris, 1-283. 
Submit or recommend next manuscript to SCIRP and we will provide best service for you:

Accepting pre-submission inquiries through Email, Facebook, LinkedIn, Twitter, etc.

A wide selection of journals (inclusive of 9 subjects, more than 200 journals)

Providing 24-hour high-quality service

User-friendly online submission system

Fair and swift peer-review system

Efficient typesetting and proofreading procedure

Display of the result of downloads and visits, as well as the number of cited articles

Maximum dissemination of your research work

Submit your manuscript at: http://papersubmission.scirp.org/

Or contact ojg@scirp.org 